\title{
Economic Analysis of Carrot (Daucus carota L.) Under Seed Priming and Pelleting in Combination with Different Crop Geometry
}

\author{
Pramod Sharma $^{1 *}$, Ashok Kumar Thakur ${ }^{2}$ and Sanjeev Kumar ${ }^{3}$
}

\author{
${ }^{1}$ Dept. of Seed Science and Technology, Dr. Y. S. Parmar University of Horticulture and Forestry, Nauni, Solan, Himachal \\ Pradesh (173 230), India \\ ${ }^{2}$ Regional Horticultural Research and Training Station, Dr. Y. S. Parmar University of Horticulture and Forestry, Nauni, Solan, \\ Himachal Pradesh (173 230), India \\ ${ }^{3}$ School of Agriculture, Shoolini University, Solan, Himachal Pradesh (173 229), India
}

\section{Corresponding Author}

Pramod Sharma

e-mail: sharmapramod827@gmail.com

\author{
Article History \\ Article ID: IJEP0363 \\ Received in $06^{\text {th }}$ March, 2020 \\ Received in revised form $20^{\text {th }}$ March, 2020 \\ Accepted in final form $28^{\text {th }}$ March, 2020
}

\begin{abstract}
The present study was conducted at experimental farm of Department of Seed Science and Technology, Dr. Y. S. Parmar University of Horticulture and Forestry, Nauni, Solan (H.P.) during the years 2017-18 and 2018-19 under priming and pelleting in combination with different crop geometry to improve carrot production for maximizing economic returns. The economics of carrot under different treatment combinations was worked out to find the most economical treatment combination. It was concluded that the treatment combination seed primed for 4 days in PEG 6000 solution having osmotic potential of $-1.2 \mathrm{MPa}$ and pelleted with Melia azedarach leaf powder sown at paired row $30+15 \times 10 \mathrm{~cm}\left(\mathrm{~T}_{1} \mathrm{G}_{2}\right)$ was more profitable as compare to other treatment combinations as net returns as well as $\mathrm{BC}$ ratio (2.31) was higher under this combination as compare to other treatment combinations.
\end{abstract}

Keywords: Carrot, economics, production

\section{Introduction}

Carrot is one of the most popular and versatile root crop in the world. Carrot production can be a profitable market for small-scale farmers and resource-poor growers, as carrots are short-duration crops and higher produce can be obtained per unit area (Ahmad et al., 2005). In terms of area, production and market value, carrot is among the top ten most economically important vegetable crops in the world (Fontes and Vilela, 2003). Most of the world's carrot production occurs in temperate countries. The leading carrot producing countries are China, USA, Russian Federation and European countries. In India, carrot is grown in an area of 97000 hectares with an annual production of 1648000 MT in the year 2017-18 (NHB, 2018), this indicates the economic importance of carrot. The main carrot growing states are Uttar Pradesh, Assam, Karnataka, Andhra Pradesh, Punjab and Haryana. The carrot has the most economic importance among root vegetables due to high content of vitamin $A$, a smooth texture and a good taste (Filgueira, 2008). European carrot is rich in bioactive compounds like carotenoids and good source of vitamin A, thiamin, protein, calcium, riboflavin and vitamin C. Its root is valued as food mainly for high carotene content, Beta carotene, having high vitamin $\mathrm{A}$ activity (Biesalski, 1997) which constitute 60 to $90 \%$ of carrot carotenoids (Simon and Wolff, 1987). Nutrient composition of carrot root includes moisture $86 \mathrm{~g}$, protein $0.9 \mathrm{~g}$, carbohydrate $10.6 \mathrm{~g}$, fat $0.2 \mathrm{~g}$, fiber $1.2 \mathrm{~g}$, energy 48 kilo calorie, mineral $1.1 \mathrm{~g}$, iron $2.2 \mathrm{mg}$, carotene $1890 \mathrm{mg}$, thiamine $0.04 \mathrm{mg}$, riboflavin $0.02 \mathrm{mg}$, niacin $0.5 \mathrm{mg}$, vitamin C $3 \mathrm{mg}$, folic acid $15 \mathrm{mg}$, calcium $80 \mathrm{mg}$ and phosphorus $30 \mathrm{mg}$ per $100 \mathrm{~g}$ of edible portion (Bose and Som, 2000). Carrot roots contain sucrose 10 times higher than that of glucose or fructose. Good quality seed not only raise productivity per unit area but also contribute to achieve predictable crops without any admixtures required for reasonable or fair market prices (Pal et al., 2019). However, the key problem faced by carrot growers is that the necessary quantity of good quality seed is not sufficient, which requires standardization of production technology in order to produce a high yield of quality carrot roots (Kumar et al., 2017). Seed priming and seed pelleting found more appropriate to overcome these problem related to seed quality to improve productivity of carrot. Also, finding the most suitable spacing or crop geometry is therefore very 
important in order to achieve higher productivity with good quality roots that lead to higher economic benefits. Keeping in a view, present study was taken to analyze economics of carrot under priming and pelleting in combination with different crop geometry.

\section{Materials and Methods}

The present investigation was conducted at experimental farm of Department of Seed Science and Technology, Dr. Y. S. Parmar University of Horticulture and Forestry, Nauni, Solan (H.P.) during the years 2017-18 and 2018-19. This experiment comprised of four different crop geometry viz. $30 \times 10 \mathrm{~cm}$ (Recommended), paired row $30+15 \times 10 \mathrm{~cm}$, paired row $45+15 \times 10 \mathrm{~cm}$ and paired row $75+15 \times 10 \mathrm{~cm}$ and best four selected treatments from priming and pelleting treatment combination viz. seeds primed for 4 days with PEG 6000 solution having osmotic potential of $-1.2 \mathrm{MPa}$ and pelleted with Melia azedarach leaf powder, seed primed for 2 days with PEG 6000 solution having osmotic potential of $-1.2 \mathrm{MPa}$ and pelleted with Vitex negundu leaf powder, seed primed for 4 days with PEG 6000 solution having osmotic potential of $-1.2 \mathrm{MPa}$, seed primed for 4 days with PEG 6000 solution having osmotic potential of $-1.0 \mathrm{MPa}$ and pelleted with Melia azedarach leaf powder along with control. So as to have 20 treatment combinations which were planned and executed under field experiment. Economics of carrot crop under different treatment combinations was worked out using following formulae:

Gross returns $=$ Output of crop $\times$ Price

Net returns $=$ Gross returns - Total Cost of Cultivation

$\mathrm{BC}$ ratio $=$ (Gross return/ Total cost of cultivation)

\section{Results and Discussion}

Economic analysis is essential to test the profitability and viability of any activity. Therefore, the economics of traditional carrot (without plant protection chemicals) vis-à-vis different treatment combinations (priming and pelleting in combination with different crop geometry) was worked out and have been presented in Table 1 and 2. The data in Table 1 revealed that per hectare cost of cultivation of carrot was Rs. 105930 with total variable cost of Rs. 74680 and total fixed cost of Rs. 31249.

The results in Table 2 pointed out maximum yield was obtained under treatment combination seed primed for 4 days in PEG 6000 solution having osmotic potential of $-1.2 \mathrm{MPa}$ and pelleted with Melia azedarach leaf powder sown at paired row $30+15 \times 10 \mathrm{~cm}\left(\mathrm{~T}_{1} \mathrm{G}_{2}\right)$ (177.11 quintal ha-1) treatment combination and minimum (71.63 quintal ha ${ }^{-1}$ ) was under control sown at paired row $75+15 \times 10 \mathrm{~cm}\left(\mathrm{~T}_{5} \mathrm{G}_{4}\right)$. Among different treatment combinations, highest net returns (Rs. $150541 \mathrm{ha}^{-1}$ ) was obtained from $\mathrm{T}_{1} \mathrm{G}_{2}$ treatment combination i.e. seed primed for 4 days in PEG 6000 solution having osmotic potential of -1.2 MPa and pelleted with Melia azedarach leaf

\begin{tabular}{llc}
\hline \multicolumn{2}{l}{ Table 1: Cost of cultivation of carrot $\left(₹\right.$ ha $\left.^{-1}\right)$} \\
\hline Sr. No. & Cost Items & Rs. \\
\hline A. & Variable Cost & \\
\hline & Human Labour & 36500 \\
& Machinery cost & 8400 \\
& Seed & 12000 \\
& FYM & 13500 \\
& Miscelleneous & 1408 \\
& Interest on working capital & 2872 \\
& Total Variable cost & 74680 \\
B. & Fixed Cost & \\
\hline & Land revenue & 31 \\
& Rental value of land & 30000 \\
& Depreciation & 543 \\
& Interest on fixed capital & 675 \\
& Total fixed cost & 31249 \\
C. & Total cost of cultivation & 105929 \\
\hline
\end{tabular}

Table 2: Economics of carrot for different treatment combination

\begin{tabular}{|c|c|c|c|c|c|}
\hline $\begin{array}{l}\text { Treatment } \\
\text { combina- } \\
\text { tions }\end{array}$ & $\begin{array}{l}\text { Total cost } \\
\text { of cultiva- } \\
\text { tion }\left(₹ \text { ha }^{-1}\right)\end{array}$ & $\begin{array}{l}\text { Yield } \\
\left(\mathrm{q} \mathrm{ha} \mathrm{H}^{-1}\right)\end{array}$ & $\begin{array}{l}\text { Gross } \\
\text { returns } \\
(₹)\end{array}$ & $\begin{array}{l}\text { Net } \\
\text { returns } \\
\text { (₹) }\end{array}$ & $\begin{array}{l}B: C \\
\text { Ratio }\end{array}$ \\
\hline $\mathrm{T}_{1} \mathrm{G}_{1}$ & 113362 & 94.56 & 141840 & 28478 & 1.25 \\
\hline $\mathrm{T}_{1} \mathrm{G}_{2}$ & 115124 & 177.11 & 265665 & 150541 & 2.31 \\
\hline $\mathrm{T}_{1} \mathrm{G}_{3}$ & 113362 & 143.56 & 215340 & 101978 & 1.90 \\
\hline $\mathrm{T}_{1} \mathrm{G}_{4}$ & 106985 & 106.85 & 160275 & 53290 & 1.50 \\
\hline $\mathrm{T}_{2} \mathrm{G}_{1}$ & 113362 & 98.11 & 147165 & 33803 & 1.30 \\
\hline $\mathrm{T}_{2} \mathrm{G}_{2}$ & 115124 & 138.78 & 208170 & 93046 & 1.81 \\
\hline $\mathrm{T}_{2} \mathrm{G}_{3}$ & 113362 & 111.56 & 167340 & 53978 & 1.48 \\
\hline $\mathrm{T}_{2} \mathrm{G}_{4}$ & 106985 & 92.15 & 138225 & 31240 & 1.29 \\
\hline $\mathrm{T}_{3} \mathrm{G}_{1}$ & 110236 & 119.56 & 179340 & 69104 & 1.63 \\
\hline $\mathrm{T}_{3} \mathrm{G}_{2}$ & 113563 & 169.44 & 254160 & 140597 & 2.24 \\
\hline $\mathrm{T}_{3} \mathrm{G}_{3}$ & 109631 & 120.48 & 180720 & 71089 & 1.65 \\
\hline $\mathrm{T}_{3} \mathrm{G}_{4}$ & 106253 & 98.22 & 147330 & 41077 & 1.39 \\
\hline $\mathrm{T}_{4} \mathrm{G}_{1}$ & 111642 & 105.85 & 158775 & 47133 & 1.42 \\
\hline $\mathrm{T}_{4} \mathrm{G}_{2}$ & 113625 & 149.09 & 223635 & 110010 & 1.97 \\
\hline $\mathrm{T}_{4} \mathrm{G}_{3}$ & 111253 & 126.52 & 189780 & 78527 & 1.71 \\
\hline $\mathrm{T}_{4} \mathrm{G}_{4}$ & 106854 & 97.7 & 146550 & 39696 & 1.37 \\
\hline $\mathrm{T}_{5} \mathrm{G}_{1}$ & 105929 & 82.89 & 124335 & 18406 & 1.17 \\
\hline $\mathrm{T}_{5} \mathrm{G}_{2}$ & 108542 & 136.93 & 205395 & 96853 & 1.89 \\
\hline $\mathrm{T}_{5} \mathrm{G}_{3}$ & 105929 & 91.04 & 136560 & 30631 & 1.29 \\
\hline $\mathrm{T}_{5} \mathrm{G}_{4}$ & 105634 & 71.63 & 107445 & 1811 & 1.02 \\
\hline
\end{tabular}

Table 2: Continue... 
Treatments: $\mathrm{T}_{1}=$ PEG 6000-1.2 MPa 4days+Melia azedarach+clay; $\mathrm{T}_{2}=\mathrm{PEG} 6000-1.2 \mathrm{MPa} 2$ days+Vitex negundu + clay; $\mathrm{T}_{3}=$ PEG 6000-1.2 MPa 4 days + unpelleted; $\mathrm{T}_{4}=$ PEG 6000-1.0 MPa 4 days + Melia azedarach+clay; $\mathrm{T}_{5}=$ Control; Crop Geometry: $\mathrm{G}_{1}=30 \times 10 \mathrm{~cm}$ (Recommended); $\mathrm{G}_{2}=$ Paired row $30+15 \times 10 \mathrm{~cm} ; \mathrm{G}_{3}=$ Paired row $45+15 \times 10$ $\mathrm{cm} ; \mathrm{G}_{4}=$ Paired row $75+15 \times 10 \mathrm{~cm}$

powder sown at paired row $30+15 \times 10 \mathrm{~cm}$ and minimum (Rs. $1811 \mathrm{ha}^{-1}$ ) was from $\mathrm{T}_{5} \mathrm{G}_{4}$ treatment combination i.e. control sown at paired row $75+15 \times 10 \mathrm{~cm}$. It was observed that all the treatments with crop geometry $\mathrm{G} 2$ provided higher net returns as compared to treatment combination with other crop geometry. The benefit cost ratio was found highest (2.31) under treatment combination seed primed for 4 days in PEG 6000 solution having osmotic potential of -1.2 MPa and pelleted with Melia azedarach leaf powder sown at paired row $30+15 \times 10 \mathrm{~cm}\left(\mathrm{~T}_{1} \mathrm{G}_{2}\right)$ indicated that one rupee spent on carrot under this treatment combination will give 2.31 rupees in return. The benefit cost ratio was minimum (1.02) under control sown at paired row $75+15 \times 10 \mathrm{~cm}\left(\mathrm{~T}_{5} \mathrm{G}_{4}\right)$ treatment combination.

\section{Conclusion}

The analysis showed that total cost of cultivation under $T_{1} G_{2}$ was around Rs. 115124 ha $^{-1}$ with net returns of Rs. 150541. Based on the results, it was concluded that treatment combination seed primed for 4 days in PEG 6000 solution having osmotic potential of -1.2 MPa and pelleted with Melia azedarach leaf powder sown at paired row $30+15 \times 10 \mathrm{~cm}$ $\left(\mathrm{T}_{1} \mathrm{G}_{2}\right)$ was more profitable as compare to other treatment combinations as net returns as well as $B C$ ratio (2.31) was higher under this combination as compared to others.

\section{References}

Ahmad, Z., Ali, N., Ahmad, M., Ulhag, S., Ahmad, S., 2005. Yield and economics of carrot production in organic farming. Sarhad Journal of Agriculture 21, 357-364.

Biesalski, H.K., 1997. Bioavailability of vitamin A. European Journal of Clinical Nutrition 51, 1-5.

Bose, T.K., Som, M.G., 2000. Vegetable crops in India. Naya Prakash, Calcutta.

Filgueira, F.A.R., 2008. New olive growing manual: modern agrotechnology in the production and marketing of vegetables. ( $3^{\text {rd }}$ Edn) Viçosa, MG Editora UFV, 421.

Fontes, R.R., Vilela, N.J., 2003. The current status of Brazilian crops and future opportunities. Acta Horticulture 607, 135-141.

Kumar, A., Afroza, B., Zehra, S.B., Mushtaq, N., Shah, M., 2017. Economics of seed production in carrot as influenced by spacing, steckling size and umbel order. Journal of Pharmacognosy and Phytochemistry 6, 1139-1141.

NHB, 2018. National Horticulture Board Database. www. nhb.gov.in

Pal, G., K, U.B., Jeevan Kumar, S.P., Sripathi, K.V., Kumari, K., Agarwal, D.K., 2019. An economic analysis of mung bean seed production technology in Mau district of eastern Uttar Pradesh. Legume Research, 5-9.

Simon, P.W., Wolff, X.Y., 1987. Carotene in typical and dark orange carrots. Journal of Agricultural and Food Chemistry 35, 1017-1022. 